\title{
POPULATION DENSITY AND SEASONAL DISTRIBUTION OF RODENT SPECIES AT SHEEP FARMING IN EI-KAWTHER REGION, SOHAG GOVERNORATE, EGYPT Desoky ,A. S.S. ${ }^{(1)}$; S. A.S Baghdadi ${ }^{(2)}$ and H. S.K. Ahmed ${ }^{(2)}$ \\ ${ }^{1}$ Plant protection Department (Zoology), Faculty of Agriculture, Sohag University \\ ${ }^{2}$ Agric. Zoology and Nematology Dept., Faculty of Agric., Al-Azhar University \\ abdelalem2011@yahoo.com
}

\begin{abstract}
The present work aimed to give an idea about the incidence and distribution of rodents species in sheep farms at Sohag University during December, 2012 till November.2013. Results revealed the presence of three species of rats included the Lesser garbia, Gerbillus sp., (1.08\%);the Nile grass rat, Arvicanthis niloticus $(4.44 \%$.), and the white bellied rat, Rattus rattus frugivorus (94.27\%.).On the other hand, the highest populations of rodent species were recorded in spring $(34.41 \%)$ and summer (29.03\%) followed by autumn (20.79\% and winter (15.77\%), respectively.

Keywords: dominant species, Lesser garbia, the Nile grass rat, the white bellied rat

\section{INTRODUCTION}

Rats and mice are possibly the most damaging rodents based on economic losses and health-related issues. They are constantly associated with unsanitary habitats, such as sewers and pit latrines and thrive in overcrowded apartments. It has been reported that nearly 4 million rats are born every day and 10 rats for every human alive (Health and Medical News,2003). High abundance is expected to lead to more contact between humans and rats resulting more than ever to debilitating rat borne zoonoses with the increased density of human population (Davis et al., 2005).

In Egypt, the changes of the environment by reclamation the desert and increase the cover plant in this area have been a great effect to the distribution of rodent species on abundance in the studied area (El-Sherbiny, 1987; Desoky, 2007 and Abdel-Gawad (2010). Our study aims to identify the rodent species and its seasonal changes to be used in the development of a future plan in effective strategy for implementation of rodent management programs in cultivated and newly reclaimed agro ecosystems in Egypt.
\end{abstract}

\section{MATERIALS AND METHODS}

The present work was carried out in the experimental station of the Faculty of Agriculture, El-Kawther region, Sohag University during December, 2012 till November.2013. It is located in newly reclaimed area at the Eastern desert area as arid region (15km. East of Sohag Governorate). This area has been planted from along period about (30 years) with isolated patches of vegetables, wheat, Egyptian clover, alfalfa and certain orchards.

Fifteen wire-box traps were distributed twice every 15 days at $6 \mathrm{pm}$ and collected at $7 \mathrm{am}$. The captured rodents were classified and recorded. The 
percentage of every species was estimated as a percent from total rodents captured during the year dominant percentage (D \%).

Dominant percentage $=$ Number of rodent species $/$ Total rodents captured $^{*} 100$

\section{RESULTS AND DISCUSSION}

The results show in the experimental station of the Faculty of Agriculture, El-Kawther region, Sohag University Data in table (1) indicated the presence of three rodent species of rats included the Lesser garbia, Gerbillus sp. was recorded (1.08\%) from newly reclaimed area; while the Nile grass rat, Arvicanthis niloticus recorded (4.44\%.) This may be attributed to the availability of food in neighbored field crops and vegetables plantations also, but the white bellied rat, $R$. $r$. frugivorus was the dominant specie recorded $(94.27 \%$.) This may be due to the presence of attributed to the availability of food and shelter as will as preferring trees for nesting. This may be due to the inter-specific competition between this species and other species.

Generally, R.r.frugivorus was the most dominant species in the sheep Farm during study period, beside the several factors e.g., intra-specific competition, fecundity increasing and in habitat the ecosystems in which poultry buildings established in the Faculty farm the presence of palm trees in the preparation of farm animal production, or poultry farm nearby, this provides shelter and increase in feed stores.

This finding is in agreement with Abo Elmaged (1998), who recorded five species of rodents Mus musculus, A. niloticus, Rattus norvegicus, Rattus rattus alexandrinus and $R$. r. frugivorus, in the animal farm of the Faculty of Agric. Assiut University. Also, Desoky(2011) found that rodents trapped from animal-farm, Assiut University during the period from 2007 to 2010 years. were: the white bellied rat, $R$. $r$. frugivorus (Linnaeus) represented by $52.86 \%$, the grey-bellied rat, R. r. alexandrinus (Linnaeus), represented by $28.74 \%$ and the Nile grass rat, represented by A.niloticus (Desmarest), (18.40\%).

Data in table (2) showed the average seasonal abundance of rodent species captured. A. niloticus was observed in winter $2.15 \%$ from the population studied followed by summer $1.79 \%$ and autumn $0.72 \%$. The absence population was recorded during spring. This may be due to that some of $A$. niloticus have to enter the farm sheep in the absence of food and shelter in the fields, either in the case of the provision of food and shelter, especially in periods of pre-harvest and harvest that do not pertain to farm sheep and for this reason are no spring. El-Deeb et al., (1992) in Fayoum, Minia and Sharkia governorates of Egypt, noticed that of A.niloticus (Desm.) had two peaks after the harvesting periods of winter (wheat and barley) and Summer (maize and rice) crops. 
Table (1): List of rodent species collected from sheep Farm, El-Kawther region, Sohag University, during December 2012 till November 2013.

\begin{tabular}{|l|c|c|c|}
\hline Family species & No. & $\%$ & Common name \\
\hline $\begin{array}{l}\text { Fam. Cricetidae: } \\
\text { Gerbillus sp. (Olivier) }\end{array}$ & 3 & 1.08 & Lesser garbia \\
\hline $\begin{array}{l}\text { Fam. Muridae: } \\
\text { Arvicanthis niloticus (Desmarest) }\end{array}$ & 13 & 4.66 & $\begin{array}{c}\text { Field rat, grass rat, } \\
\text { Nile rat and Nile } \\
\text { grass rat }\end{array}$ \\
\hline $\begin{array}{l}\text { Rattus rattus frugivorus } \\
\text { (Linnaeus) }\end{array}$ & 363 & 94.27 & $\begin{array}{c}\text { white bellied rat, } \\
\text { date palm rat }\end{array}$ \\
\hline Total & 279 & 100 & \\
\hline
\end{tabular}

Table (2) Seasonal distribution of certain rodent species at sheep farming, El Kawther region, Sohag University, during December, 2012 till November 2013.

\begin{tabular}{|l|c|c|c|c|c|c|c|c|}
\hline \multirow{3}{*}{ Seasons } & \multicolumn{8}{|c|}{ Rodent species } \\
\cline { 2 - 9 } & \multicolumn{1}{|c|}{ A. niloticus } & \multicolumn{1}{c|}{ R.r. frugivorus } & Gerbillus sp. & \multicolumn{2}{c|}{ Total } \\
\cline { 2 - 9 } & No. & $\%$ & No. & $\%$ & No. & $\%$ & No. & $\%$ \\
\hline Winter & 6 & 2.15 & 38 & 13.62 & 0 & 0 & 44 & 15.77 \\
\hline Spring & 0 & 0 & 95 & 34.05 & 1 & 0.36 & 96 & 34.41 \\
\hline Summer & 5 & 1.79 & 74 & 26.52 & 2 & 0.72 & 81 & 29.03 \\
\hline Autumn & 2 & 0.72 & 56 & 20.07 & 0 & 0 & 58 & 20.79 \\
\hline
\end{tabular}

In the same results, $R$. $r$. frugivorus was observed in spring representing $34.05 \%$ from the population studied followed by summer $26.52 \%$ and autumn $20.07 \%$. The lowest population was recorded during spring $13.62 \%$. This may be due to the provision of food and shelter, such as palm trees in this region and increase reproductive efficiency in the spring and summer of this type. Also the existence of competition within the members of the same species and members of other species. Abdel-Gawad (1987) recorded, three rodent species A. niloticus (Desm.), $R$. rattus frugivorus and Gerbillus spp Desm., in Wady El-Assiuty area, Assiut governorate. He noticed that, A. niloticus (Desm.) preferred areas planted with the field crops and some parts under cultivation beside old cultivated land while $R$. r. frugivorus was found in citrus orchards and around fanners buildings, whereas Gerbillus spp Desm., lived in desert and semi-desert parts where wild plants and weeds were grown.

On the other hand, results showed that Gerbillus sp. was observed in summer represented by $0.72 \%$ from the population followed by spring $0.36 \%$ . The absence population during winter and autumn may be due to the farm located in newly reclaimed area, intervened some desert rats to sheep farm at times, to the farm near the residence of the desert rats, and an escape from high temperature .Abdel-Galil (2005) in Assiut governortae, recorded the roof rat Rattus rattus, occurred abundantly followed by the Norway rat Rattus norvegicus, the Nile grass rat $A$. niloticus and the demsy rat Gerbillus pyramidium, respectively in field crop. In the houses habitat, the highest index 
was recorded with the Norway rat $R$. norvegicus, while the Nile grass rat, $A$. niloticus and the demsy rat, $G$. pyramidium were completely absent.

Generally, the population dynamics showed that, high population of rodents was observed during spring with $34.41 \%$ followed by summer $29.03 \%$ and the lowest population was counted during autumn and winter with $20.79 \%$ and $15.77 \%$.

\section{CONCLUSION}

1- The differences in species composition of rodents depending on locality, habitat type and preferred food.

2- High population density of rodents occurred in spring and summer were increased activity. However, the lowest density was during winter and autumn season.

3- The control of rodents depends upon the locality, neighboring and available food and can be used effectively in an Integrated Pest Management Approach (IPMA) for the regulation of the rodents population density.

\section{REFERENCES}

Abdel-Galil, Y. M. A. (2005). Comparative studies on rodenticides against some rodents. Ph.D., Thesis Fac. Agric., Al-Azhar Univ.

Abdel-Gawad, K. H. (1987). Seasonal distribution of rodent species and their associated ectoparasites in new cultivated lands. Assiut J. Agric. Sc., 18 (3): 343-352.

Abdel-Gawad K. H. (2010). Rodent species composition in the present compared with past, the 5 Scientific Conferences for Agric. Assiut Univ. Oct. 16-17, 2010 (159-167).

Abo Elmaged, T. M. (1998). Recent trends for controlling some harmful arthropods in the husbandry, M. Sc. Thesis, Fac. Agric., Assiut Univ., Assiut, Egypt.

Ali, M. K. (1985). Studies on rodents and their ectoparasites in Sohag Governorate. M. Sc. Thesis Fac. Agric., Assiut Univ., 82 PP.

Health and Medical News (2003). Rat borne disease on the rise : scientists warn .http://www.abc.net.au/science/news/health.23 $3^{\text {rd }}$ may2007.

Davis, S., E. Calvet and H .Leirs (2005).Fluctuating rodent population and the risk to human from rodent borne zoonoses. Vector Borne and Zoonotic Diseases,5(4):305-314.

Desoky, A.S. S. (2007). Management strategies for rodents within different ecosystems. M. Sc. Thesis, Fac. Agric. Assiut Univ. 124.

Desoky, A.S.S. (2011) Studies on Certain Ectoparasites Associated with Some Farm Animals and their Control, Ph.D. Thesis, Fac. Agric., Assiut Univ., Assiut, Egypt. 179 pp.

El-Deeb,H. I.; Lokma, H.E. and El-Fishawi, A. A. (1992). Fields studies on population dynamics and reproductive biology of the Nile rat, $A$. niloticus. Zagazig J. Agric. Res., 9 (3): 1431-1435. 
El-sherbiny A. H. (1987). Cyclic fluctuation in rodent population: Review of current researches. Egypt wild and not resources Vo: 19 pp 17.

$$
\begin{aligned}
& \text { الكثافـه العدديـه والتوزيـع الموسـي لأنـواع القـوارض في مزرعـة الاغتـام بمنطقة }
\end{aligned}
$$

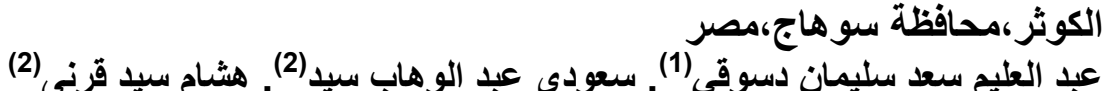

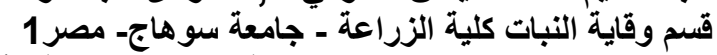

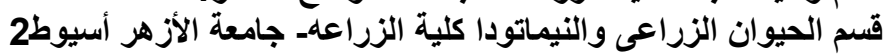

$$
\begin{aligned}
& \text { abdelalem2011@yahoo.com }
\end{aligned}
$$

الغرض من هذه الدراسة التعرف علي أنواع القو ارض المختلفة و نوزيعها الموسمي بمدينـة

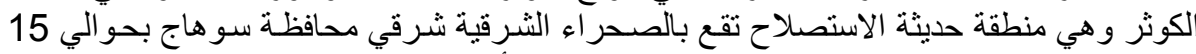

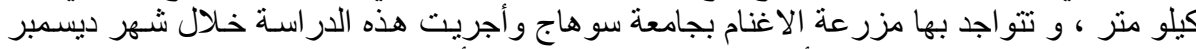

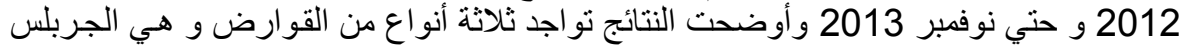

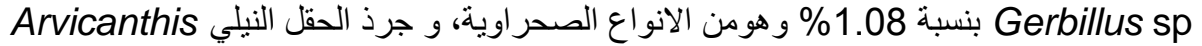
Rattus rattus frugivorus 4.44 niloticus و جرذ النخيل ذو البطن البيضة \%94.27

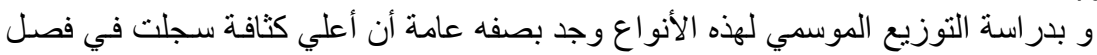

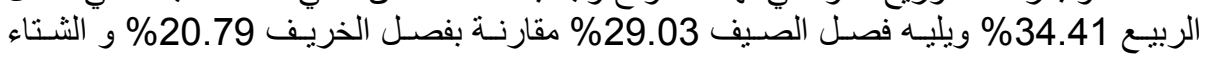
15.77\%.ولكن بصفه خاصة اختلفت التذبذبات الموسمية لبعض الانو اع لإختلاف الظروف البيئة

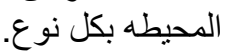

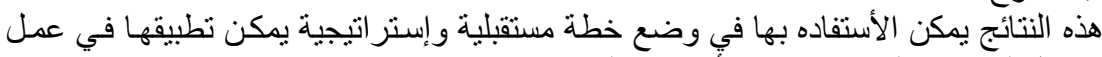

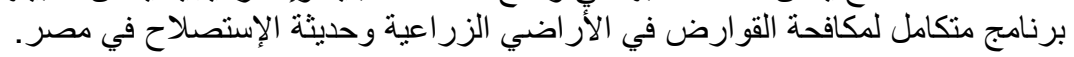

